\title{
Climate change, food security and mycotoxins: do we know enough?
}

\author{
Angel Medina, Asya Akbar, Alaa Baazeem, Alicia Rodriguez \& Naresh Magan
}

Applied Mycology Group, Environment and AgriFood Theme, Cranfield University,

Cranfield, Bedford MK43 0AL, U.K.

Corresponding author: Prof. N. Magan, Applied Mycology Group, AgriFood Theme, School of Energy,

Environment and AgriFood, Cranfield MK43 OAl, U.K.

E-mail:n.magan@cranfield.ac.uk

Key words: temperature, drought stress, carbon dioxide, mycotoxigenic fungi, mycotoxin production 


\section{Abstract}

Climate change (CC) scenarios are predicted to have significant effects on the security of staple commodities. A key component of this impact is the infection of such crops by mycotoxigenic moulds and contamination with mycotoxins. The impacts of CC on mycotoxigenic fungi requires examination of the impacts of the threeway interactions between elevated $\mathrm{CO}_{2}(350-400$ vs $650-1200 \mathrm{ppm})$, temperature increases $\left(+2-5^{\circ} \mathrm{C}\right)$ and drought stress on growth/mycotoxin production by key spoilage fungi in cereals and nuts. This review examines the available evidence on the impacts of interacting CC factors on growth and mycotoxin production by key mycotoxigenic fungi including Alternaria, Aspergillus, Fusarium and Penicillium species. Aspergillus flavus responsible for producing aflatoxin $B_{1}\left(A F B_{1}\right)$ is a class $1 A$ carcinogen and its growth appears to be unaffected by CC factors. However, there is a significant stimulation of $\mathrm{AFB}_{1}$ production both in vitro and in vivo in maize. In contrast, studies on Aspergillus section Circumdati and Nigri species responsible for ochratoxin $A$ contamination of a range of commodities and $F$. verticillioides and fumonisins suggest that some species are more resilient than others, especially in terms of mycotoxin production. Acclimatisation of mycotoxigenic fungal pathogens to CC factors may result in increased disease and perhaps mycotoxin contamination of staple cereals. Predictive modelling approaches to help identify regions where maximum impact may occur in terms of infection by mycotoxigenic fungi and toxin contamination of staple crops is hindered by the lack of reliable inputs on effects of the interacting CC factors. The present available knowledge is discussed in the context of the resilience of staple food chains and the impact that interacting CC factors may have on the availability of food in the future.

\section{Introduction}

Climate change (CC) is predicted to have significant impacts on the quality and availability of staple food commodities. Food security is determined by three key components: (a) sufficient food availability, (b) access to this food and (c) quality and utilisation of the food in terms of both nutritional and cultural perspectives (FAO, 1998). With the predicted increase in the population on a global basis, the present intensive inputs into staple cereals and rice will only provide marginal increases in yields. Thus, the capacity to provide additional food of the necessary quality/quantity in the coming 25-50 years has been questioned (Battilani et al., 2012; IPCC, 2013; Battilani et al., 2016). In the context of CC impacts, especially changes in global weather patterns, could have a profound impact on the production and delivery of enough staple foods (Paterson and Lima, 2010; 2011; Wu et al., 2011).

The European Food Safety Authority (EFSA) has examined the potential impact of CC in Europe and has suggested that effects will be (a) regional and (b) detrimental or advantageous depending on geographical region (Battilani et al., 2012). This suggests that in northern Europe the effects may be positive, while the Mediterranean basin may be a hot spot where many effects will be negative, with extreme changes in rainfall/drought, elevated temperatures and $\mathrm{CO}_{2}$ impacting on food production. Effects of $\mathrm{CC}$ on cereals 
will be significant and detrimental as ripening in southern and central Europe will occur much earlier than at present. This will influence pests and diseases with decreasing yields and increasing mycotoxin contamination. Indeed it has been suggested that CC may be responsible for up to a $1 / 3$ of yield variability in key staple commodities on a global basis (Ray et al., 2015). This will have profound impacts on food security in different continents.

Based on present available data, atmospheric concentrations of $\mathrm{CO}_{2}$ are expected to double or triple (from 350-400 to $800-1200 \mathrm{ppb)} \mathrm{in} \mathrm{the} \mathrm{next} \mathrm{25-50} \mathrm{years.} \mathrm{Thus,} \mathrm{different} \mathrm{regions} \mathrm{in} \mathrm{Europe} \mathrm{mentioned}$ previously will be impacted by the increases in temperature of $2-5^{\circ} \mathrm{C}$ coupled with elevated $\mathrm{CO}_{2}(800-1200$ ppm) and drought episodes. This will have profound impacts on pests and diseases and ultimately yields (Gregory et al., 2009; Bebber et al., 2013; Bebber et al., 2014; Bebber and Gurr, 2015). Similar impacts have been predicted in other areas of the world, especially parts of Asia, and Central and South America which are important producers of wheat, maize and soya beans for food and feed uses on a global basis (IPCC, 2013).

Historically, concerns about the contamination of food and feed with mycotoxins originally arose in the 1960s when a significant number of turkey poults died from eating feed found to be contaminated with Aspergillus flavus and aflatoxin $\mathrm{B}_{1}\left(\mathrm{AFB}_{1}\right)$, later found to be a Class $1 \mathrm{~A}$ carcinogen by the International Agency for Research on Cancer (IARC) (IARC, 2012). More information on the background, history and importance of mycotoxins in food/feed chains can be found in a timely review by Pitt and Miller (2017). The focus on mycotoxins has been a high priority by the FAO and WHO because of their significant toxicological impacts on both human and animal health. This has resulted in strict legislative limits for mycotoxins in many parts of the world in a wide range of foodstuffs with the strictest limits in the EU (European Commission, 2006). However, in many African countries where legislation is often applied to export crops only, consumption of mycotoxin contaminated staple foods is a significant risk, especially in rural populations and sub-groups such as children and immunocompromised people.

The most important mycotoxins are aflatoxins (produced by Aspergillus section Flavi species), ochratoxin A (OTA) (Aspergillus section Circumdati species, Aspergillus section Nigri species, Penicillium nordicum, P. verrucosum), fumonisins (Fusarium verticillioides, F. sporotrichioides), type A trichothecenes, T2 and HT-2 toxin (F. langsethiae, F. sporotrichioides), and type B trichothecenes (F. graminearum and related species) and patulin ( $P$. expansum). EFSA are now examining the relative hazard posed by mycotoxins produced by Alternaria species across the EU to obtain information of the levels in different food products to make decisions on whether limits should be considered. The ecophysiology and toxicology of Alternaria toxins have been recently extensively reviewed (Lee et al., 2015).

The relative resilience of different staple food and feed chains has thus become important in the context of whether increased or decreased mycotoxin contamination may occur as well as impacts on the 
nutritional value. The inherent value of staple grains such as maize, wheat and rice are approx. 15.1, 14.2 and $5.4 \mathrm{~kJ} / \mathrm{g}$. It has been previously shown that mycotoxigenic fungi in maize can cause significant impacts on both calorific value as well as increase contamination with mycotoxins (Marin et al., 1999; Ramos et al., 1999). Thus, the perspectives on CC impacts are related to both nutritional/quality losses and toxin exposure, especially in Low and Middle Income Countries (LMICs). It is thus important when examining potential impacts of CC scenarios, to consider interactions between elevated $\mathrm{CO}_{2}$, temperature and drought stress together. The environmental changes occurring now are slowly but steadily shaping the relationship between plant growth and the associated fungal diseases and pest populations. Indeed, the traditional and classic balanced triangle between pathogen/pest, host plant and environment (Garrett, 2008; Grulke, 2011) is changing and becoming skewed because of the relative importance and pressure of the environmental component which may shape both plant agronomy and ultimately yield of key staple foods (Pautasso et al., 2012; Figure 1). This shift in these interactions could be in a state of flux depending on the push and pull of the interacting factors and have significant impacts on the food supply chains in terms of food quality and quantity necessary to satisfy a rapidly expanding world population. Fungal plant pathogens are predicted to move globally and change the diversity of diseases and pests invading staple crops with both economic and social costs (Bebber \& Gurr, 2015; Medina et al., 2015a). Recent predictions by Bebber et al. (2013) suggest that pests and diseases are migrating to the poles at the rate of 3-5 km/year, with the diversity of pest populations becoming significantly changed (Crespo et al., 2015). In the context of mycotoxigenic fungal pathogens this could result in a switch from so-called mycotoxin suppressive to mycotoxin conducive conditions. Environmental stress has been shown to have significant consequences for secondary metabolite production, especially mycotoxins (Schmidt-Heydt et al., 2011; Medina et al., 2015c). Pest damage of ripening crops, especially cereals, can predispose them to infection/colonisation by mycotoxigenic fungal pathogens leading to increased mycotoxin contamination. Thus, while these previous studies did not focus on mycotoxigenic fungi, this does suggest significant potential impacts on mycotoxin contamination of staple foods/crops (Battilani et al., 2012; Battilani et al., 2016a). Indeed, a recent UNEP report on “Emerging Issues of Environmental Concern" (UNEP, 2016) has included a section entitled "Poisoned chalice: Toxin accumulation in crops in an era of climate change" which refers to the impact that aflatoxin contamination is having in LMICs. Wild et al. (2015) also showed that consumption of staple foods based on maize/groundnuts which are often contaminated with high levels of $\mathrm{AFB}_{1}$, produced by Aspergillus section Flavi species, in the diet of infants and children in LMICs is resulting in significant stunting of growth. Thus, CC factors could have impacts and consequences because of the potential impacts on food availability, levels of mycotoxin contamination and the consumption of staple foods predominantly based on cereals.

Many of the current predictions and hypotheses towards the real effect of CC on fungal diseases and mycotoxigenic fungi are based on historical or current climatic conditions datasets that predominantly 
consider interactions between water availability and temperature (Battilani et al., 2016a). Very few research studies have examined the effect of 3-way interactions between these identified environmental factors (temperature, water availability and $\mathrm{CO}_{2}$ ) and what changes in terms of the ecophysiology of mycotoxigenic fungi and effects on mycotoxin production might occur (Medina et al., 2014; 2015a,b; Vary et al., 2015; Vaughn et al., 2014; Akbar et al., 2016; Magan and Medina, 2016).

\section{Impact of climate change factors on growth and mycotoxin production}

Impact of water activity $\left(a_{w}\right) \times$ temperature interactions on growth and mycotoxin production

Over the last three decades work has been focused on the impact that $\mathrm{a}_{w} \mathrm{x}$ temperature factors have on growth and mycotoxin production by a wide range of mycotoxigenic fungi (Sanchis and Magan, 2004; Magan and Aldred, 2007a; Magan et al., 2010). This has included data on the optimum/marginal conditions for growth, mycotoxin production, and the boundary conditions for germination, growth and toxin production in vitro and in some cases in situ in key relevant commodities. This has usually shown that the range of $a_{w} x$ temperature for mycotoxin production is narrower than that for growth. The only exception, to our knowledge, is Penicillium verrucosum which grows and produces ochratoxin A (OTA) under a very similar range of $a_{w} x$ temperature conditions (Cairns et al., 2005). However, extreme drought episodes, desertification and fluctuations in wet/dry cycles will have an impact on the life cycles of mycotoxigenic fungi (Magan et al., 2011).

Magan et al. (2011) reviewed some of the available ecological data on optimum and marginal interacting conditions of $a_{w} x$ temperature for growth and mycotoxin production by several mycotoxigenic species which was done by examining effects of drought stress conditions and +3 or $+5^{\circ} \mathrm{C}$ temperature change. These have now been updated to include more data which has become available (Medina et al., 2015c). This shows that mycotoxigenic fungi would normally grow slower and produce, in most cases, similar or lower amounts of mycotoxins under the temperature $x a_{w}$ stress (Table 1). However, in some cases, such as for A. flavus, it is able to grow and produce $\mathrm{AFB}_{1}$ under higher temperatures and efficiently colonize maize, groundnuts and tree nuts under drought conditions. Thus, in CC hot spot areas this could become an emerging problem mainly in the Mediterranean and other temperate regions. Field studies suggest that there are impacts of CC based on maize. For example in Serbia, there was no aflatoxin contamination in maize in the 2009-2011 seasons. However, prolonged hot and dry weather in 2012 resulted in 69\% of samples being contaminated with aflatoxins (Kos et al., 2012). Similarly, in Hungary, it was shown that an increase in aflatoxins may be due to CC conditions (Dobolyi et al., 2013).

However, there are only a few concrete examples of incidences where CC factors have been implicated. Changes in water and temperature stress may impact on Aspergillus section Nigri species and influence OTA contamination of grapes and grape-based products. Also, there may be changes in mycotoxin 
prevalence among the same species (Chiotta et al., 2014; Garcia-Cela et al., 2014; Gil-Serna et al., 2014). Alternaria alternata produces mycotoxins such as alternariol $(\mathrm{AOH})$, alternariol monomethyl ether (AME) and altenuene $(A E)$. While for $\mathrm{AOH}$ maximum production is at $21^{\circ} \mathrm{C}$ and $0.95 \mathrm{a}_{\mathrm{w}}, \mathrm{AME}$ production was maximum at the same $a_{w}$ levels but at much warmer conditions, $35^{\circ} \mathrm{C}$. Thus, increases in temperature may equate to shifts from $\mathrm{AOH}$ to $\mathrm{AME}$ under the forecasted conditions (Vaquera et al., 2014). Interacting environmental stresses such as $a_{w} x$ temperature may also affect ratios of related compounds. For example, F. graminearum produces type B trichothecenes (deoxynivalenol, 3-acetyl and 15-acetyl DON). Changing $a_{w}$ $x$ temperature affects the ratio of the former three compounds both in vitro and in wheat grain (Figure 2; Leite, 2014). Also for $F$. verticillioides and the production of fumonisins (fumonisin $B_{1}, B_{2}, B_{3}, B_{4}$ ) $a_{w} x$ temperature conditions can significantly change the ratio of these toxins in colonised maize (Mylona, 2013; Table 2). This has implications for mycotoxin contamination of staple food crops under CC scenarios as there could be a switch from the dominant mycotoxins produced to other related compounds which could become the predominant toxic contaminants.

Furthermore, in the last few years there has been a growing interest in the relationship between quantifiable "free mycotoxins" and the so called "masked mycotoxins". Bound mycotoxins are covalently or non-covalently attached to polymeric carbohydrate or protein matrices. For example, DON can be converted to deoxynivalenol-3-D-glucopyranoside (D3G) in wheat, and the latter is difficult to detect using conventional analytical analyses. These compounds are mainly produced by plants and have been related to detoxification and resistance mechanisms exhibited by plants to counteract pathogen infection (Lemmens et al., 2005; Cirlini et al., 2012). Although by themselves they often exert lower toxicity than the original mycotoxins, some of them have been demonstrated to partially or totally cleaved under gastrointestinal conditions, resulting in similar toxic effects as their parent compound (Dall'Erta, 2013). However, to date there has been no research to examine how different environmental conditions, particularly CC related changes, will affect the production of these compounds, relative to the mycotoxins detected. As has been pointed out earlier, marked changes in plant physiology will change the pathogen-host relationship under CC factors. Research is thus needed to study whether these changes will lead to changes in these plant protection mechanisms and whether this leads to increased or decreased contamination with these compounds. The relative amount of free and masked mycotoxins may change under CC scenarios and this may require more detailed analyses in the near future.

Three way water activity $\left(a_{w}\right) \times$ temperature $x \mathrm{CO}_{2}$ interactions on growth and mycotoxin production

The interactions of elevated temperature $\mathrm{CO}_{2}$ and extreme fluxes in drought/flooding conditions are the research areas which are now being addressed. This is because it has become clear that ecophysiological effects on plant growth and the interface with fungal disease/pest infestation could be profoundly changed. 
Thus the doubling of current $\mathrm{CO}_{2}$ levels by the 2050s' and tripling around 2100s, will have profound effects on all living species globally, with plants and fungal species being no exception. In general, photosynthesis, leaf area, plant height, total biomass and crop yield, sugar and starch content, water-use efficiency, growth, and yield have been shown to increase in the presence of higher levels of $\mathrm{CO}_{2}$, especially in cereals (Eastburne et al., 2010; Vaughan et al., 2014; Ray et al., 2015; Vary et al., 2015). While fungi are tolerant of elevated $\mathrm{CO}_{2}$ alone, when combined with other environmental factors they are less tolerant (Magan and Aldred, 2007b). Thus, tolerance of interacting CC factors where perhaps a doubling of existing $\mathrm{CO}_{2}$ is predicted (350-400 to $700-800 \mathrm{ppm}$ ) to occur may not be problematic for the growth of many mycotoxigenic fungi. However, the growth patterns of mycotoxigenic fungi are affected by the three-way interacting conditions of temperature $x$ water stress $x$ elevated $\mathrm{CO}_{2}$ (350 vs $1000 \mathrm{ppm}$ ). This was shown to affect growth of F. graminearum and F. verticillioides (Medina et al., 2015c). This is supported by the predicted effects of CC conditions on fungal diseases of staple grains (Chakraborty and Newton, 2011; Juroszek et al., 2011; Medina et al., 2015a) which all suggest changes in the host/pathogen interface impacting on food security. Increases or decreases in fungal disease symptoms, infection and/or pest fecundity will also contribute to the impacts on crop agronomy, yield and quality (Ziska et al., 2004; Dixon, 2012). $\mathrm{CO}_{2}$ may also influence resilience of cereal crops and plant resistance to plant diseases (Plazek et al., 2001). A recent study also suggest that pest control using entomogenous fungi may be less effective under CC conditions which could further impact on levels of crop damage and influence mycotoxin contamination (Borisade and Magan, 2015).

Only a few studies have tried to obtain scientific data to expose economically important crops to CC conditions and examine effects on the plant, fungal infection and mycotoxin contamination. Vaughan et al. (2014) investigated the impact of elevated $\mathrm{CO}_{2}$ on the interactions between maize and $F$. verticillioides. They found that elevated $\mathrm{CO}_{2}$ of approx. 800 ppm $\mathrm{CO}_{2}$ (approx. 2 x current $\mathrm{CO}_{2}$ ) increased maize susceptibility to $F$. verticillioides colonisation. Interestingly, fumonisin $B_{1}\left(F B_{1}\right)$ production was unaffected by these interactions. They found that $\mathrm{FB}_{1}$ contamination was not proportional to the increase in the biomass of $F$. verticillioides, and the amount per unit pathogen was reduced in elevated $\mathrm{CO}_{2}$. This suggested that there were some physiological effects on maize agronomy under CC treatments, especially during silking, which impacted on $F$. verticillioides infection and the rate of contamination with fumonisins. However, drought stress was not included in the experimental design. Similar physiological effects were observed in wheat and FHB and STB diseases when $\mathrm{CO}_{2}$ was doubled (Vary et al., 2015). Previous studies have certainly suggested that a key gene in the fumonisin biosynthetic pathway (FUM 1) is significantly affected by changes in environmental stress (Marin et al., 2010).

Medina et al. (2015a) studied the impact of CC scenarios on growth and $\mathrm{AFB}_{1}$ production by $A$. flavus (NRRL type strain) on maize-based media and subsequently on stored maize grain. The treatments included: 
(a) 34 and $37^{\circ} \mathrm{C}$; (b) imposed drought stress -0.97 to 0.95 and 0.91 aw; and (c) $\mathrm{CO}_{2}$ was increased from 350 to 650 and $1000 \mathrm{ppm}$. The effects on growth of $A$. flavus and expression of some aflatoxin cluster genes $(a f I D, a f I R)$ and phenotypic $A F B_{1}$ production were examined. This was the first time a combination of expected CC factors were used to establish the potential effects of these scenarios on the ecophysiology of mycotoxigenic fungi. This showed that growth of $A$. flavus was relatively unaffected. In contrast, the threeway interacting conditions had a profound, statistically significant stimulatory effect on $\mathrm{AFB}_{1}$ production (70 $x$ the control in in vitro studies), especially under drought stress at $37^{\circ} \mathrm{C}$ and 650 and $1000 \mathrm{ppm} \mathrm{CO}_{2}$ exposure. Studies of the relative expression of the biosynthetic genes in the aflatoxin pathway also corroborated these findings (Medina et al., 2015a). Research on maize grain suggested that AFB 1 production was increased but in a lower range than in vitro on a conducive medium. Also, afID and afIR expression were increased by the interacting CC treatments. Table 3 compares some of the results obtained in vitro and on maize grain with regard to some aflatoxin cluster genes and $\mathrm{AFB}_{1}$ production. Payne et al. (2016) have suggested that RNA sequencing of the $A$. flavus genome when infecting maize kernels under interacting CC conditions would provide insights into the key groups of genes involved in the observed changes. Medina et al. (2017) have now used a transcriptomic approach and examined the impact on overall up and down regulated genes in relation to $a_{w} x$ temperature conditions and found that there are changes in relation to the secondary metabolite gene clusters (aflatoxin, cyclopiazonic acid), universal regulators, sugar transporters, other stress-related pathways. These are indicative of changes in relation to the three way interaction between CC factors. It is important to identify whether any switches in biosynthetic pathways may occur resulting in other secondary metabolites being produced rather than aflatoxins or cyclopiazonic acid by $A$. flavus under such environmental stresses.

Other recent studies with Aspergillus section Circumdati and Section Nigri species (A. wetserdijkiae, A. ochraceus, A. steynii; A. carbonarius) in vitro and on stored coffee beans in relation to OTA production under CC change conditions have been carried out (Akbar, 2015; Akbar et al., 2016). These suggest that for some species there may be a stimulation of OTA production (e.g. A. westerdijkiae) while for other species (A. carbonarius) there was a reduction in toxin contamination (Figure 3). Table 4 shows the statistical effect of the individual and interacting CC factors on all the strains and species tested (Akbar et al., 2016). This suggests that differential effects may occur for individual mycotoxigenic species and that in depth knowledge of potential impacts are needed on strains of a specific species before making predictions of the impact of CC factors in relation to an increase or decrease in mycotoxin production.

It should be noted that fungi have the ability to adapt to change, especially mycotoxigenic fungal pathogens, and may thus become of primary concern in the coming 20-25 years. Because fungi have a high degree of plasticity and are able to adapt to interacting environmental and other stresses, e.g. fungicides, they may rapidly evolve to adapt to and dominate crop ecosystems under CC conditions (Vaughan et al., 
2014; Vary et al., 2015; Battilani et al., 2016).

\section{Acclimatisation of fungal pathogens and impacts on colonisation and mycotoxin production}

There have been practically no studies on the impact that acclimatisation of crops or fungal pathogens and pests may have on the plant/disease pest interface. A recent study by Vary et al. (2015) showed that CC factors does affect the physiology of wheat with comparison of exposure to existing (390 ppm) and elevated $\mathrm{CO}_{2}(780 \mathrm{ppm})$ caused changes in leaf physiology and stomatal production on adaxial and abaxial surfaces. Of particular interest was the acclimatisation of Septoria tritici blotch (STB) disease and Fusarium Head Blight (FHB; F. graminearum) for 10-20 generations in elevated $\mathrm{CO}_{2}$. These acclimatised strains of the pathogens caused significantly increased disease progression in terms of foliar symptoms of STB and FHB and for the latter this was more pronounced and also confirmed by molecular analysis of fungal biomass. This study did not examine effects on type B trichothecenes (e.g. deoxynivalenol; 3-acetyl deoxynivalenol, 15-acetyl deoxynivalenol) which would have been interesting.

Work at Cranfield has been examining the relationship between $A$. flavus and contamination of pistachio nuts with $\mathrm{AFB}_{1}$. This is a major problem in the industry in meeting the EU legislative limits for this mycotoxin, especially from Iran and the Mediterranean region. Strains of $A$. flavus isolated from pistachio nuts grow optimally at $35^{\circ} \mathrm{C}$ and $0.98-0.95 \mathrm{a}_{\mathrm{w}}$ on a pistachio nut-based medium and on pistachio nuts. Strains were acclimatised at $37^{\circ} \mathrm{C}$ and $0.98 \mathrm{a}_{\mathrm{w}}$ for 5 generations at $1000 \mathrm{pm} \mathrm{CO}_{2}$ on a pistachio nut-based medium. These were then subsequently compared with the non-acclimatised strains in terms of growth and $\mathrm{AFB}_{1}$ production in control conditions $\left(350 \mathrm{ppm} \mathrm{CO} 2 / 35^{\circ} \mathrm{C} / 0.98 \mathrm{aw}\right)$ and under $\mathrm{CC}$ scenarios $\left(1000 \mathrm{ppm} / 37^{\circ} \mathrm{C} / 0.98\right.$ $a_{w}$ ) on layers of pistachio nuts. Figure 4 a shows the effects on growth of two strains of $A$. flavus. This shows that for 1 strain acclimatisation influenced growth while for the other strain there was no significant effect on colonisation of pistachio nuts. For this strain $\mathrm{AFB}_{1}$ production was significantly stimulated, especially after 10 days colonisation after acclimatisation, while for the other strain there was no significant increase (Figure 4b; Baazeem, Medina and Magan, unpublished data). This certainly suggests that there may be intra-strain differences in effects of acclimatisation and this may influence mycotoxin production on such commodities as mixed populations of contaminant fungi often occurs. More focus needs to be on acclimatisation of fungal pathogens and their interactions with other mycobiota and the interface with the plant to obtain more accurate data on implications for mycotoxin contamination, especially of staple crops under CC scenarios.

Increases in pest reproduction rates under acclimatisation scenarios could increase damage to ripening crops (during anthesis in wheat; silking in maize) and facilitate increased infection by mycotoxigenic fungal pathogens with potential for increased contamination with mycotoxins. Previous studies of the bioenergetics and pest utilisation of cereals suggests that associated calorific losses may be significant under present climatic conditions (Demianyk and Sinha, 1988; Campbell and Sinha, 1990). However, with increased 
fecundity under CC conditions, especially acclimatisation, will these impacts be significantly greater? The area of acclimatisation needs further investigation and could have significant implications for the prediction of impacts of CC on mycotoxigenic species of Aspergillus, Penicillium and Fusarium.

\section{Climate change and predictions of mycotoxin contamination}

Previously, modelling the potential impacts of CC scenarios on mycotoxins have focused on DON contamination of wheat in northern Europe (Van Der Fels-Klerx et al., 2012a,b) and a another study focused on aflatoxins contamination of maize, wheat and rice grown in Europe (Battilani et al., 2012; 2016). They both applied multidisciplinary inputs of information obtained from climate projections, crop phenology and fungal/mycotoxin production. Recently, Van Der Flels-Klerx et al. (2016) also examined Alternaria and its mycotoxins in tomatoes. Previous studies have also examined on a single country basis CC scenarios on FHB prediction and the change in the relative risk of contamination with mycotoxigenic species. However, many of these models have included an increase in temperature of +2 and $+5^{\circ} \mathrm{C}$, or increased $\mathrm{CO}_{2}$ levels. For the DON in wheat predictions two empirical models were integrated to include wheat phenology and DON contamination in the regions of Europe of interest. In addition climate model projections for 2031-2050 were included from various available data bases. This included projected temperature fluctuations and rainfall patterns, solar radiation and estimated were based on $50 \times 50 \mathrm{~km}$ grids across the area of interest. However, $\mathrm{CO}_{2}$ changes were not included in these data bases. These results showed that under CC was predicted a 12 weeks earlier date for flowering and maturation of winter wheat, with DON contamination expected to increase in most of the region examined based on the simulations carried out.

Battilani et al. $(2012 ; 2016)$ used IPCC CC models based on an increase in $+2^{\circ} \mathrm{C}$ and $+5^{\circ} \mathrm{C}$ to examine impacts on $\mathrm{AFB}_{1}$ in maize wheat and rice in Europe. Again meteorological data sets were obtained from the LARS weather generator and they also used a $50 \times 50$ grid system for evaluating impacts across Europe. The aflatoxin (AFLA-maize) model was a mechanistic one based on the prediction of $A$. flavus infection and AFB 1 production on a daily basis (Battilani et al., 2013). This produced an Aflatoxin Risk Index (AFI), linked to AFB 1 contamination observed in field measurements. The inputs into the model showed that the areas in which maize would be cultivated would be larger across Europe. However, the AFI index would cover a wider area of Europe with a significantly higher risk of $\mathrm{AFB}_{1}$ contamination. The hot spots for this were central Spain, Italy, and the Balkans for the $+2^{\circ} \mathrm{C}$ scenario, and a much wider range of risk regions in the $+5^{\circ} \mathrm{C}$ scenario, although in the latter case the relative $\mathrm{AFB}_{1}$ contamination would be less.

Recently a mechanistic study has examined Alternaria infection of tomatoes in two regions of Europe, in Spain (Extramadura region) and in Poland (Krobia). Using the weather inputs under different CC scenarios (Van der Perre et al., 2015; Van Der Fels-Klerx et al., 2016). These results which modelled different levels of industrial development showed that in Spain the temperature changes $\left(18.2-38.2^{\circ} \mathrm{C}\right.$ ) would minimize growth 
of Alternaria and mycotoxin contamination because at the higher temperatures growth and mycotoxin production are minimal (Lee et al., 2014); while in Poland under the projected temperatures $\left(14.2-28.4^{\circ} \mathrm{C}\right.$ ) there would be an increase in Alternaria contamination with the range being within the optimum range for production of alternariol, its monomethyl esters, altenuene and tenuazonic acid (Lee et al., 2014).

Van Der Fels-Klerx et al. (2016) have suggested that there are specific gaps in relation to predictive modelling of CC impacts on mycotoxin contamination. There has been relatively limited validation of the models with the exception of the few mentioned previously. Perhaps better inputs on efficacy of $a_{w} x$ temperature $\mathrm{x} \mathrm{CO}_{2}$ interactions on growth/mycotoxin boundary conditions are necessary to make empirical models more robust. More detailed information is necessary to input into the predictive models being developed. Van Der Fels-Klerx and Booij (2010) suggested using a geographical orientated decision support system to develop prediction on a regional or continental basis. The development of more accurate prediction really depends on the resilience of important staple food commodities under expected CC scenarios, and linking this to the life cycle for germination, growth and mycotoxin production cycle of economically important mycotoxigenic fungi especially under the three way-interacting CC variables. Furthermore, while for some fungal species growth or mycotoxin production remains similar under the forecasted CC conditions, for others, environmental changes may have significant effects, e.g., increasing toxin production or a switch in the major mycotoxin produced or the ratio of different mycotoxins. Much more data is required to enable a better understanding of the fungal and plant ecophysiology and the pathogen/host interface to improve the potential for making more accurate and relevant global predictions on the impact of mycotoxins on the food security of staple food crops.

\section{Conclusions}

There is clearly a need for more detailed information on the impact of CC scenarios on the germination, growth and mycotoxin production by the key mycotoxigenic species in the genera Aspergillus, Fusarium, Penicillium and Alternaria. It should be borne in mind that optimum conditions for growth are not always the same as for mycotoxin production. Phenological changes in crop production and the interface with the mycotoxigenic fungal pathogens under CC scenarios will further influence the levels of contamination with a specific mycotoxin. Key questions include whether under CC scenarios will mycotoxin production patterns change? Will other mycotoxins at present considered of secondary importance become more abundant and thus more important in the future? What is going to happen with masked mycotoxins? Are the current control/mitigation strategies going to be effective in the future? Will interactions between mycotoxigenic fungi and other microbiota in the phyllosphere and in the rhizosphere ecological niches change resulting in different community structures and dominance of different species? Will the agricultural practices, including Good Agricultural Practices and Hazard Analysis Critical Control Point management systems currently used have to change in order to minimize mycotoxin contamination when marked environmental shifts and fluxes 
become the norm? Are mycotoxigenic fungal populations going to shift their location in the coming years, as has been predicted for other fungal diseases? This may of course be intimately linked to pest population shifts and changes in diversity and their movement globally. More research is required to address these key questions to effectively predict the level of risk of different mycotoxins in economically important staple food crops and to understand whether they are resilient enough to tolerate the expected CC conditions. Existing global players in the agrifood market include countries such as Brazil and Argentina and parts of Asia including China and India. These regions and parts of Africa are considered hot spots for the impacts of CC. Thus, from a food security perspective these questions need to be addressed for more accurate prediction of the impacts of CC. Without this type of information food sustainability may well be compromised in many regions of the world, with LMICs taking the brunt of the impacts possibly resulting in negative social consequences.

\section{References}

Akbar, A., 2015. Growth and ochratoxin a production by Aspergillus species in coffee beans: impact of climate change and control using $\mathrm{O}_{3}$. PhD thesis, Cranfield University.

Akbar, A., Medina, A. \& Magan, N. (2016). Impact of climate change factors on growth and ochratoxin A production by Aspergillus sections Circumdati and Nigri species on coffee. World Mycotoxin J. 9, 863-874.

Battilani, P., Rossi, V., Giorni, P., Pietri, A., Gualla, A., Van der Fels-Klerx, H.J., Booij, C.J.H., Moretti, A., Logrieco, A., Toscano, P., Miraglia, M., De Santis, B. and Brera, C., 2012. Modelling, predicting and mapping the emergence of aflatoxins in cereals in the EU due to climate change. Scientific/Technical Report submitted to EFSA. Available at: http://www.efsa.europa.eu/en/supporting/pub/223e.htm.

Battilani, P., Toscano, P., Van der Fels-Klerx, H.J., Moretti, A., Camardo Leggieri, M., Brera, C., Rortais, A., Goumperis, T. and Robinson, T., 2016. Aflatoxin $B_{1}$ contamination in maize in Europe increases due to climate change. Scientific Reports 6: 24328 doi:10.1038/srep24328.

Bebber, D.P., Ramotowski, M.A.T., Gurr, S.J., 2013. Crop pests and pathogens move poleward in a warming world. Nature Climate Change 3, 985-988.

Bebber, D.P., Holmes, T., Gurr, S.J., 2014. The global spread of crop pests and pathogens. Global Ecol. Biogeo. 23, 1398-1407.

Bebber, D.P. and Gurr, S.J., 2015. Crop-destroying fungal and oomycete pathogens challenge food security. Fungal Gen. Biol. 74, 62-64.

Borisade, O.A., Magan, N., 2015. Resilience and relative virulence of strains of erntomopathogenic fungi under interactions of abiotic stress. African J. Microbiol. Res. 9, 988-1000.

Dall'Erta, A., Cirlini, M., Dall'Asta, M., Del Rio, D., Galaverna, G., Dall'Asta C., 2013. Masked mycotoxins are efficiently hydrolyzed by human colonic microbiota releasing their aglycones. Chem Res Toxicol., 26 (3), 305312 
Cairns-Fuller, V., Aldred, D., Magan, N., 2005. Water, temperature and gas composition interactions affect growth and ochratoxin A production by isolates of Penicillium verrucosum on wheat grain. J. Appl. Microbiol. 99, 1215-1221.

Campbell, A. and Sinha, R.N., 1990. Analysis and simulation modelling of population dynamics and bioergetics Cryptolesies ferrugineus (Coleoptera: Cucujidae) in stored wheat. Res. Pop. Ecolo. 32, 235-254.

Cirlini, M., Dall'Asta, C., Galaverna, G., 2012. Hyphenated chromatographic techniques for structural characterization and determination of masked mycotoxins, J. Chromatogr. A, 1255, 145-152.

Chakraborty, S., Newton A.C., 2011. Climate change, plant diseases, and food security, an overview. Plant Pathol. 60, 2-14.

Chiotta, M.L., Sosa, D.M., Ponsone, M.L., Chulze, S.N. 2014. Effect of water activity and temperature on growth of Aspergillus carbonarius and Aspergillus tubingensis and their interactions on ochratoxin $A$ production. World Mycotoxin J. 8, 99-105.

Crespo-Perez, V., Regniere, J., Chuine, I., Rebaudo, F. \& Dangles, O., 2015. Changes in the distribution of multispecies pest asemblages affect levels of crop damage in warming tropical Andes. Glob. Change Biol. 21, 82-96.

Dixon, G. R., 2012. Climate change impact on crop growth and food production, and plant pathogens. Can. J. Plant Pathol. 34, 362-379.

Demianyk, C.J. and Sinha, R.N., 1988. Bioenergetics of the largergrain borer Prostephanus truncates (Horn) (Coleoptera:Bostrichidae) feeding on corn. Ann. Ento. Soc. Am. 81,449-459.

Dobolyi, C., Sebők, F., Varga, J., Kocsubé, S., Szigeti, G., Baranyi, N., Szécsi, Á., Tóth, B., Varga, M., Kriszt, B., Szoboszlay, S., Krifaton, C., Kukolya, J., 2013. Occurrence of aflatoxin producing Aspergillus flavus isolates in maize kernel in Hungary. Acta Alimen. 42, 451-459.

Eastburn, D.M., DeGennaro, M.M., DeLucia, E.H., Dermody, O., McElrone, A.J., 2010. Elevated atmospheric carbon dioxide and ozone alter soybean diseases at SoyFACE. Glob. Change Biol. 16, 320-330.

García-Cela, E., Crespo-Sempere, A., Ramos, A.J., Sanchis, V., Marin, S. 2014. Ecophysiological characterization of Aspergillus carbonarius, Aspergillus tubingensis and Aspergillus niger isolated from grapes in Spanish vineyards. Int. J. Fd. Microbiol.

$173,89-98$.

Garrett, K. A., 2008. Climate change and plant disease risk. In D. A. Relman, M. A. Hamburg, E. R. Choffnes, \& A. Mack (Eds.), Global climate change and extreme weather events: understanding the contributions to infectious disease emergence (pp. 143-155). Washington, DC: National Academies Press.

Gil-Serna, J., Vázquez, C., García Sandino, F., Márquez Valle, A., González-Jaén, M.T., Patiño, B., 2014. Evaluation of growth and ochratoxin A production by Aspergillus steynii and Aspergillus westerdijkiae in green-coffee based medium under different environmental conditions. Food Res. Int. 61, 127-131.

Grulke, N. E., 2011. The nexus of host and pathogen phenology: understanding the disease triangle with climate change. New Phytol. 189, 8-11. 
Gregory, P.J., Johnson, S.N., Newton et al., 2009. Integrating pests and pathogens into the climate change/food security debate. J. Exp. Bot. 60, 2827-2838.

Food and Agriculture Organization (FAO), 1996. Rome Declaration on Food Security and World Food Summit Plan of Action. FAO, Rome Italy.

IARC. 2012. Agents Classified by the IARC Monographs. Vol. 1e104 International Agency for Research on Cancer. Available at: http://monographs.iarc.fr/ENG/Classification/index.php

IPCC., 2013. Intergovernmental panel on climate change report. Climate Change 2013 in Synthesis Report (Geneva), 52.

Juroszek, P., von Tiedemann, A., 2011. Potential strategies and future requirements for plant disease management under a changing climate. Plant Path. 60, 100-112.

Kos, J., Mastilović, J., Janić Hajnal, E., Šarić, B., 2013. Natural occurrence of aflatoxins in maize harvested in Serbia during 2009-2012. Food Cont. 34, 31-34.

Lee, H.B., Patriarca, A. \& Magan, N., 2015. Alternaria in food: ecophysiology, mycotoxin production and toxicology. Mycobiology 43, 93-106.

Leite, G., 2014. Potential for control of spoilage and mycotoxigenic species using mixtures of anti-oxidants, aliphatic acids and molecular approaches using RNAi. PhD Thesis, Cranfield University.

Lemmens, M., Scholz, U., Berthiller, F., Dall'Asta, C., Koutnik, A., Schuhmacher, R., Adam, G., Buerstmayr, H., Mesterházy, Á., Krska, R., Ruckenbauer, P., 2005. The ability to detoxify the mycotoxin deoxynivalenol colocalizes with a major quantitative trait locus for fusarium head blight resistance in wheat. Molecular Plant-Microbe Interactions 18 (12), 1318-1324.

Magan, N., Aldred, D., 2007a. Environmental fluxes and fungal interactions: maintaining a competitive edge. In: Stress in yeasts and filamentous fungi. Eds. P.van West, S. Avery \& M. Stratford, 2007a. Elsevier Ltd., Amsterdam, Holland.

Magan, N., Aldred, D., 2007b. Post-harvest control strategies: minimizing mycotoxins in the food chain. Int. J. Fd. Microbiol. 119, 131-139.

Magan, N., Aldred, D., Mylona, K. \& R.J.M. Lambert., 2010. Limiting mycotoxins in wheat. Food Add. Contam. 27, 644-650

Magan, N., Medina, A., Aldred, D., 2011. Possible climate change effects on mycotoxin contamination of food crops pre- and post-harvest. Plant Pathol. 60, 150-163.

Magan, N. and Medina, A., 2016. Integrating gene expression, ecology and mycotoxin production by Fusarium and Aspergillus species in relation to interacting environmental factors. World Mycotoxin J. 9, 863874.

Marin, S., Homedes, V., Sanchis, V. and Magan, N., 1999. Impact of Fusarium moniliforme and F. proliferatum on calorific losses and fumonisin production under different environmental conditions. J. Stored Prod. Res. 35, 15-26. 
Marín, P., Magan, N., Vázquez, C. \& González-Jaén, M.T., 2010. Differential effect of environmental conditions on growth and regulation of the fumonisin biosynthetic gene FUM1 in the maize pathogens and fumonisin-producers F. verticillioides and F. proliferatum. FEMS Microbiol. Ecol. 73, 303-311

Medina, A., Rodriguez, A. \& Magan, N., 2014. Effect of climate change on Aspergillus flavus and aflatoxins. Front. Microbiol. 5, 348-354.

Medina, A., Rodríguez, A., Sultan, Y., Magan, N., 2015a. Climate change factors and A. flavus: effects on gene expression, growth and aflatoxin production. World Mycotoxin J. 8, 171-179.

Medina, A., Rodriguez, A., Magan, N., 2015b. Effect of climate change on Aspergillus flavus and aflatoxins. Front. Microbiol. 5, 99-104.

Medina, A., Rodriguez, A. \& Magan, N., 2015c. Changes in environmental factors driven by climate change: effects on the ecophysiology of mycotoxigenic fungi. Climate change and Mycotoxins, Eds. Luis M. Botana \& María J. Sainz. 2015, De Gruyter, Berlin, Germany.

Mylona, K., 2013. Fusarium species in grains: dry matter losses, Mycotoxin contamination and control strategies using ozone and chemical compounds. PhD Thesis. Cranfield University.

Paterson, R.R.M, Lima, N., 2010. How will climate change affect mycotoxins in food? Food Res. Int. 43, 19021914.

Paterson, R.R.M., Lima, N., 2011. Further mycotoxin effects from climate change. Food Res. Int. 44, 25552566.

Pautasso, M., Döring, T.F., Garbelotto, M., Pellis, L. and Jeger, M.J. 2012. Impacts of climate change on plant diseases-opinions and trends. Eur. J. Plant Pathol. 133, 295-313.

Pitt, J.I., Miller, J.D. 2017. A concise history of mycotoxin Research. J. Agric. Food Chem. In Press. DOI: 10.1021/acs.jafc.6b04494.

Plazek, A., Hura, K., Rapacz, H., Zur. I. 2001. The influence of ozone fumigation on metabolic efficiency and plant resistance to fungal pathogens. J. Appl. Bot. 75, 8-13.

Ray, D.K., Gerber, J.S., MacDonald, G.K. \& West, P.C., 2015. Climate variation explains a third of global crop yield variability. Nature Comms., 2015. DOI 10.1038/ncomms6989

Ramos, A.J., Munoz, J., Marin, S., Sanchis, V. \& Magan, N., 1999. Calorific losses in maize due to colonisation by isolates of Aspergillus ochraceus under different environmental conditions. J. Cereal Sci. 29, 177-183.

Sanchís, V., Magan, N., 2014. Environmental profiles for growth and mycotoxin production. In Mycotoxins in food: detection and control. Edts, N. Magan and M. Olsen. 2004, Woodhead Publishing Ltd.

United nations Environmental Programme (UNEP), 2016. UNEP Frontier 2016 Report. Emerging Issues of Environmental Concern. United Nations Environment Programme, Nairobi, Kenya.

Van der Fels-Klerx, H. and Booij, C., 2010. Perspectives for geographically oriented management of Fusarium mycotoxins in the cereal supply chain. J. Food Prot. 73, 1153-1159. 
Van der Fels-Klerx, H., Goedhart, P., Elen, O., Börjesson, T., Hietaniemi, V. and Booij, C., 2012a. Modelling deoxynivalenol contamination of wheat in northwestern Europe for climate change assessments. J. Food Prot. 75, 1099-1106.

Van der Fels-Klerx, H.J., Liu, C. and Battilani, P., 2016. Modelling climate change impacts on mycotoxin contamination. World Mycotoxin J. 9, 717-726.

Van de Perre, E., Jacxsens, L., Liu, C., Devlieghere, F. and De Meulenaer, B., 2015. Climate impact on Alternaria moulds and their mycotoxins in fresh produce: the case of the tomato chain. Food Res. Int. 68, 41-46.

Vary, Z., Mullins, E., Mcelwain, J.C. \& Doohan, F., 2015. The severity of wheat diseases increases when plants and pathogens are acclimatised to elevated carbon dioxide. Glob. Change Biol. 21, 2661-2669.

Vaughan, M.M., Huffaker, A., Schmelz, E.A., Dafoe, N.J., Christensen, S., Sims, J., 2014. Effects of elevated $\mathrm{CO}_{2}$ on maize defence against mycotoxigenic Fusarium verticillioides. Plant Cell. Environ. 37, 2691-2706.

Vaquera, S., Patriarca, A., Fernández Pinto, V., 2014. Water activity and temperature effects on growth of Alternaria arborescens on tomato medium. Int. J. Fd. Microbiol. 185, 136-139.

Wild, C.P., Miller, J.D. and Groopman, J.D., 2015. Mycotoxin Control in Low- and Middle Income Countries. IARC Working Group Report No. 9. International Agency for Research on Cancer, 150 cours Albert Thomas, 69372 Lyon Cedex 08, France

Wu, F., Bhatnagar, D., Bui-Klimke, T., Carbone, I., Hellmich, R., Munkvold, G., Payne, G., Takle, E., 2011. Climate change impacts on mycotoxin risks in US maize. World Mycotoxin J. 4, 79-93.

Ziska, L.H., Morris, C.F., Goins, E.W., 2004. Quantitative and qualitative evaluation of selected wheat varieties released since 1903 to increasing atmospheric carbon dioxide: can yield sensitivity to carbon dioxide be a factor in wheat performance? Glob. Change Biol. 10, 1810-1819.

\section{Figure Legends}

Figure 1. Climate change factors as drivers of change in the classic Crop/fungal disease/pest and Environment triangle which may occur due to the pressure of climate change scenarios.

Figure 2. Differential production of type B trichothecenes by Fusarium graminearum on wheat grain stored at $25^{\circ} \mathrm{C}$ for 10 days at different water activity levels (from Leite, 2014).

Figure 3. Effect of existing $\left(30^{\circ} \mathrm{C}, 400 \mathrm{ppm}\right.$, different water activity condition) and climate change conditions $\left(35^{\circ} \mathrm{C}, 1000 \mathrm{ppm}\right.$; different aw conditions on (a) strain of Aspergillus westerdijkiae and (b) strain of Aspergillus carbonarius on stored coffee. Bars indicate standard error of the mean. Note: scale ranges are different for OTA production by the two strains.

Figure 4. (a) Growth rates ( $\mathrm{mm} /$ day) of non-acclimatised and acclimatised strains of $A$. flavus, AB3 and AB10 (5 generations) on layers of raw pistachio kernels incubated at $35^{\circ} \mathrm{C}+400 \mathrm{ppm} \mathrm{CO}_{2}$ or $37^{\circ} \mathrm{C}+1000 \mathrm{ppm} \mathrm{CO}_{2}$ 
at $0.98 \mathrm{a}_{\mathrm{w}}$; (b) effect of treatments on aflatoxin $\mathrm{B}_{1}\left(A F B_{1}\right)$ production. Different letters indicate significant difference $(p<0.05)$.

Table 1. Changes in growth and mycotoxin production by Alternaria, Fusarium, Aspergillus and Penicillium species as a result of an increase in temperature of 3 or $5^{\circ} \mathrm{C}$ under different water-stress conditions.

\begin{tabular}{|c|c|c|c|c|c|c|c|c|c|}
\hline & \multicolumn{4}{|c|}{ Growth } & \multicolumn{5}{|c|}{ Toxins } \\
\hline & $a_{w}$ & $\begin{array}{c}\mu \text { max } \\
\text { range / } \\
\text { Temp }\end{array}$ & $\mu+3$ & $\mu+5$ & & $a_{w}$ & $\begin{array}{c}\tau \text { max range/ } \\
\text { Temp }\end{array}$ & $\tau+3$ & $\tau+5$ \\
\hline \multirow[t]{6}{*}{$\begin{array}{l}\text { Alternaria } \\
\text { alternata }\end{array}$} & 0.95 & $2-1 / 25$ & $2-1$ & $\begin{array}{l}1- \\
0.5\end{array}$ & Altenuene & 0.95 & $100-40 / 25$ & $40-20$ & $20-5$ \\
\hline & 0.90 & $\begin{array}{c}0.1-0.5 / \\
25\end{array}$ & $\begin{array}{c}0.5- \\
0.1\end{array}$ & NG & & 0.90 & $20-5 / 25$ & $5-N P$ & NP \\
\hline & & & & & Alternariol & 0.95 & $500-100 / 25$ & $40-20$ & $20-5$ \\
\hline & & & & & & 0.90 & $20-5 / 25$ & NP & NP \\
\hline & & & & & Alternariol & 0.95 & $400-100 / 25$ & $100-10$ & NP \\
\hline & & & & & $\begin{array}{c}\text { monomethyl } \\
\text { ether }\end{array}$ & 0.90 & $100-10 / 25$ & NP & NP \\
\hline \multirow{3}{*}{$\begin{array}{l}\text { Alternaria } \\
\text { tenuissima }\end{array}$} & 0.98 & $13.5-$ & $8-$ & $7.5-$ & Altertoxin II & 0.98 & $50-150 / 30$ & $100-$ & $125-$ \\
\hline & & $14 / 30$ & 9.5 & 9 & & & & 250 & 250 \\
\hline & 0.95 & $5-6 / 30$ & $\begin{array}{l}4.5- \\
5.5\end{array}$ & $\begin{array}{c}4.5- \\
5.5\end{array}$ & & 0.95 & $\begin{array}{c}600- \\
2100 / 30\end{array}$ & $\begin{array}{l}500- \\
1000\end{array}$ & $\begin{array}{l}400- \\
1300\end{array}$ \\
\hline \multirow[t]{2}{*}{$\begin{array}{c}\text { Fusarium } \\
\text { proliferatum }\end{array}$} & 0.95 & $4-3 / 28$ & $3-2$ & $2-1$ & Fumonisin & 0.95 & $>1000 / 20$ & $\begin{array}{c}1000- \\
100\end{array}$ & $100-50$ \\
\hline & 0.90 & $\begin{array}{c}0.5- \\
0.1 / 28\end{array}$ & NG & NG & & $0.93^{a}$ & 50- $10 / 15$ & $50-10$ & $50-10$ \\
\hline \multirow[t]{2}{*}{$\begin{array}{c}\text { Fusarium } \\
\text { verticillioides }\end{array}$} & 0.95 & $4-3 / 25$ & $4-3$ & $4-3$ & Fumonisin & 0.95 & $\begin{array}{l}10000- \\
1000 / 20\end{array}$ & $\begin{array}{c}10000- \\
1000\end{array}$ & $\begin{array}{c}1000- \\
100\end{array}$ \\
\hline & 0.90 & $\begin{array}{c}0.5- \\
0.1 / 25\end{array}$ & $\begin{array}{l}0.5- \\
0.1\end{array}$ & NG & & $0.93^{a}$ & $10 / 15$ & $50-10$ & $50-10$ \\
\hline \multirow[t]{2}{*}{$\begin{array}{l}\text { Fusarium } \\
\text { culmorum }\end{array}$} & 0.95 & $3-1 / 20$ & $3-1$ & $3-1$ & DON & 0.95 & $1-0.25 / 20$ & $\begin{array}{c}0.25- \\
0.1\end{array}$ & $\begin{array}{l}0.1- \\
0.01\end{array}$ \\
\hline & 0.90 & $1-0.1 / 20$ & $\begin{array}{l}1- \\
0.1\end{array}$ & $\begin{array}{l}1- \\
0.1\end{array}$ & & $0.93^{a}$ & $\begin{array}{c}0.25- \\
0.01 / 20\end{array}$ & NP & NP \\
\hline \multirow[t]{2}{*}{$\begin{array}{c}\text { Fusarium } \\
\text { graminearum }\end{array}$} & 0.95 & $>4 / 20$ & $4-2$ & $2-1$ & DON & 0.95 & $1-0.1 / 20$ & $1-0.1$ & $\begin{array}{l}0.1- \\
0.01\end{array}$ \\
\hline & 0.90 & $1-0.1 / 20$ & $\begin{array}{l}1- \\
0.1\end{array}$ & $\begin{array}{l}1- \\
0.1\end{array}$ & & $0.93^{a}$ & NP & NP & NP \\
\hline \multirow[t]{2}{*}{$\begin{array}{c}\text { Fusarium } \\
\text { langsethiae }\end{array}$} & 0.98 & $\begin{array}{c}4.6- \\
5.1 / 25\end{array}$ & $\begin{array}{c}4.6- \\
4.1\end{array}$ & $\begin{array}{c}3.6- \\
3.1\end{array}$ & $\mathrm{~T}-2+\mathrm{HT}-2$ & 0.98 & $10-11 / 25$ & $13-14$ & $14-15$ \\
\hline & 0.95 & $\begin{array}{c}2.6- \\
2.1 / 25\end{array}$ & $\begin{array}{c}1.1- \\
1.6\end{array}$ & $\begin{array}{c}1.6- \\
1.1\end{array}$ & & 0.95 & $0-1 / 25$ & $0-1$ & $0-1$ \\
\hline
\end{tabular}




\begin{tabular}{|c|c|c|c|c|c|c|c|c|c|}
\hline \multirow[t]{2}{*}{$\begin{array}{c}\text { Aspergillus } \\
\text { westerdijkiae }\end{array}$} & 0.95 & $5-4.5 / 30$ & $\begin{array}{c}4.45- \\
3.95\end{array}$ & $\begin{array}{c}4.25- \\
3.75\end{array}$ & Ochratoxin A & 0.95 & $\begin{array}{l}1065.7- \\
1014.9 / 30\end{array}$ & $\begin{array}{c}719.4- \\
685.1\end{array}$ & $\begin{array}{l}488.5- \\
465.3\end{array}$ \\
\hline & 0.90 & $\begin{array}{c}1.85- \\
1.35 / 30\end{array}$ & $\begin{array}{c}1.85- \\
1.35\end{array}$ & $\begin{array}{l}1.80- \\
1.30\end{array}$ & & 0.90 & $\begin{array}{c}54.1- \\
51.6 / 30\end{array}$ & $\begin{array}{c}51.6- \\
49.2\end{array}$ & $\begin{array}{c}49.9- \\
47.6\end{array}$ \\
\hline \multirow[t]{2}{*}{$\begin{array}{l}\text { Aspergillus } \\
\text { carbonarius }\end{array}$} & 0.95 & $>6 / 30$ & $>6$ & $6-5$ & Ochratoxin A & 0.95 & $\begin{array}{c}2000-1500 \\
/ 20\end{array}$ & $\begin{array}{c}1000- \\
500\end{array}$ & $500-N P$ \\
\hline & 0.90 & $4-3 / 30$ & $4-3$ & $4-3$ & & 0.90 & $\begin{array}{c}1000-500 \\
/ 20\end{array}$ & $\begin{array}{l}500- \\
\text { NP }\end{array}$ & $500-N P$ \\
\hline \multirow[t]{2}{*}{ Aspergillus flavus } & 0.95 & $6.9 / 35$ & 5.6 & 5.0 & Aflatoxin B1 & 0.95 & $\begin{array}{c}3082-2278 \\
\text { / } 37\end{array}$ & $\begin{array}{c}102- \\
138\end{array}$ & $6.1-N P$ \\
\hline & 0.90 & $2.9 / 37$ & 1.4 & 0.7 & & 0.90 & $\begin{array}{c}448.5-331.5 \\
/ 37\end{array}$ & 1-NP & NP \\
\hline \multirow[t]{3}{*}{$\begin{array}{l}\text { Penicillium } \\
\text { verrucosum }\end{array}$} & 0.97 & $\begin{array}{c}2.2- \\
2.4 / 25\end{array}$ & $\begin{array}{l}1.8- \\
1.9\end{array}$ & $0.9-1$ & Ochratoxin A & 0.97 & $60-50 / 20$ & $75-70$ & $>80$ \\
\hline & 0.95 & $3-4 / 25$ & $4-3$ & $3-2$ & & 0.95 & $>50 / 20$ & $>50$ & $50-25$ \\
\hline & 0.90 & $\begin{array}{l}2.5- \\
1 / 25\end{array}$ & $2-1$ & $\begin{array}{l}2- \\
0.5\end{array}$ & & 0.90 & $50-30 / 20$ & $50-30$ & $\begin{array}{c}50-30 \\
\left(5-3^{a}\right)\end{array}$ \\
\hline \multirow[t]{3}{*}{$\begin{array}{c}\text { Penicillium } \\
\text { nordicum }\end{array}$} & 0.97 & $\begin{array}{c}1.4- \\
1.5 / 20\end{array}$ & 1.5 & $2-1$ & Ochratoxin A & 0.97 & $7-6 / 20$ & $6-5$ & $4-3$ \\
\hline & 0.94 & $\begin{array}{c}1.8- \\
2.0 / 20\end{array}$ & $\begin{array}{l}1.8- \\
1.7\end{array}$ & $\begin{array}{l}1.4- \\
1.7\end{array}$ & & 0.94 & $7-6 / 20$ & $7-6$ & $7-6$ \\
\hline & 0.90 & $\begin{array}{c}1.2- \\
1.3 / 20\end{array}$ & $\begin{array}{l}1.2- \\
1.3\end{array}$ & $\begin{array}{l}1.2- \\
1.4\end{array}$ & & 0.90 & $8-7 / 20$ & $9-8$ & $9-8$ \\
\hline \multirow[t]{3}{*}{$\begin{array}{l}\text { Penicillium } \\
\text { expansum }\end{array}$} & 0.98 & $9.1 / 20$ & & & Patulin & 0.98 & $3.5-0.55 / 20$ & NS & NS \\
\hline & 0.95 & $\begin{array}{c}6.9-5.5^{a} \\
/ 25\end{array}$ & $\begin{array}{c}6.9- \\
5.5\end{array}$ & $\begin{array}{c}6.9- \\
5.5\end{array}$ & & 0.95 & NS & NS & NS \\
\hline & 0.90 & $\begin{array}{c}2.9- \\
1.6^{a} / 25\end{array}$ & $\begin{array}{c}2.9- \\
1.6\end{array}$ & $\begin{array}{c}2.9- \\
1.6\end{array}$ & & 0.90 & NS & NS & NS \\
\hline
\end{tabular}

$\mu$ max: Maximum growth rate $\left(\mathrm{mm}\right.$ day $\left.^{-1}\right) ; \mu+3$ : Growth rate increasing 3 centigrade degrees; $\mu+5$ Growth rate increasing 5 centigrade degrees; $\tau$ max: Maximum toxin production $\left(\mu \mathrm{g} \mathrm{ml}^{-1}\right) ; \tau+3$ : Predicted toxin increasing 3 centigrade degrees; $\tau+5$ : Predicted toxin increasing 5 centigrade degrees; NG, no growth; NP, no toxin production; NS, not studied.

For Aspergillus and Penicillium species: $\tau$ max: Maximum toxin production $\left(\mathrm{ng} \mathrm{g}^{-1}\right) ; \tau+3$, predicted toxin production with $3^{\circ} \mathrm{C}$ increase; $\tau+5$, predicted toxin production with $5^{\circ} \mathrm{C}$ increase.

a Minimum water availability for toxin production.

Table 2. The ratio of the four fumonisins $\left(\mathrm{FB}_{1}, \mathrm{FB}_{2}, \mathrm{FB}_{3}, \mathrm{FB}_{4}\right)$ produced by Fusarium verticillioides when colonising maize at different temperatures and water activities for 10 days. The ratios in bold indicate changes in relative amounts of the two mycotoxins.

(a) Ratio of $\mathrm{FB}_{1} / \mathrm{FB}_{2}$

Temperature $\left({ }^{\circ} \mathrm{C}\right) \quad 15$

Water activity $\left(\mathrm{a}_{\mathrm{w}}\right)$

0.97

0.95

0.91

5.86

6.80

5.79

(b) Ratio $\mathrm{FB}_{1} / \mathrm{FB}_{3}$

0.97

0.95
20

4.28

4.69

7.67
25

4.95

5.33

5.07
30

7.61

5.81

6.67 
(c) Ratio $\mathrm{FB}_{2} / \mathrm{FB}_{3}$

$\begin{array}{lllll}0.97 & 2.78 & 1.48 & 1.82 & 0.86 \\ 0.95 & 1.62 & 1.65 & 1.24 & 1.07 \\ 0.91 & 2.14 & 1.83 & 2.51 & 1.97\end{array}$

(d) Ratio $\mathrm{FB}_{2} / \mathrm{FB}_{4}$

$\begin{array}{lllll}0.97 & 11.53 & \mathbf{5 . 2 2} & \mathbf{8 . 4 6} & \mathbf{9 . 0 6} \\ 0.95 & 16.16 & \mathbf{6 . 3 1} & \mathbf{7 . 2 4} & \mathbf{7 . 6 7} \\ 0.91 & 10.05 & 13.29 & 13.55 & 14.17\end{array}$

Table 3. Relative effect of interacting climate change environmental factors $\left(+3^{\circ} \mathrm{C} ; 1000 \mathrm{ppm} \mathrm{CO2}\right.$; drought stress) on $A$. flavus growth, a regulatory gene $(a f I R)$ in the biosynthetic pathway for aflatoxin production and aflatoxin $\mathrm{B}_{1}$ production (a) in vitro and (b) on stored maize grain. Numbers refer to fold variation relative to the controls at $30^{\circ} \mathrm{C}$ and $350 \mathrm{ppm} \mathrm{CO} 2$ and the same $\mathrm{a}_{\mathrm{w}}$ levels (data for (a) from Medina et al., 2015a; (b) unpublished data; Medina, Rodriguez \& Magan).

(a) A. flavus growth on an In vitro on a conducive medium (10 days)

\begin{tabular}{|c|c|c|c|c|}
\hline \multirow[t]{3}{*}{ Temperature $\left({ }^{\circ} \mathrm{C}\right)$} & $a_{w}$ & $\mathrm{CO}_{2}$ (ppm) & aflR & Aflatoxin $B_{1}$ \\
\hline & 0.97 & 650 & $=$ & $=$ \\
\hline & & 1000 & $=$ & $=$ \\
\hline \multirow[t]{6}{*}{34} & 0.95 & 650 & $\bar{Z}$ & $=$ \\
\hline & & 1000 & & \\
\hline & 0.92 & 650 & $\mathbb{1}(x 2$ & $(\times 2.8)$ \\
\hline & & 1000 & $\uparrow(x 2$ & 12 \\
\hline & 0.97 & 650 & $=$ & 30.7 \\
\hline & & 1000 & $=$ & $(x 23.8$ \\
\hline \multirow[t]{4}{*}{37} & 0.95 & 650 & $\widehat{T}(x)$ & $(x 79.2$ \\
\hline & & 1000 & $\underline{\top}(x 4$ & 78.5 \\
\hline & 0.92 & 650 & $\boldsymbol{I}(\times 4$ & $(x) 15.1$ \\
\hline & & 1000 & $\mathbf{I}(\mathrm{x} 1$ & $1 \times 23.8$ \\
\hline
\end{tabular}

(b) A. flavus colonisation of stored maize grain (10 days)

\begin{tabular}{|c|c|c|c|c|}
\hline Temperature $\left({ }^{\circ} \mathrm{C}\right)$ & $a_{w}$ & $\mathrm{CO}_{2}(\mathrm{ppm})$ & $a f I R$ & Aflatoxin $B_{1}$ \\
\hline \multirow[t]{4}{*}{30} & 0.99 & 650 & $=$ & $=$ \\
\hline & & 1000 & $=$ & $=$ \\
\hline & 0.91 & 650 & $(\times 2.0)$ & $\boldsymbol{T}(\times 2.7)$ \\
\hline & & 1000 & $=$ & $=$ \\
\hline \multirow[t]{4}{*}{37} & 0.99 & 650 & $(\times 2.0)$ & $\hat{1}(x 3.6)$ \\
\hline & & 1000 & $(\times 3.0)$ & $(x 5.0)$ \\
\hline & 0.91 & 650 & $(\times 2.0)$ & $\boldsymbol{1}(x$ 1.8) \\
\hline & & 1000 & $=$ & $(x$ 1.5) \\
\hline
\end{tabular}

Table 4. Summary statistical table of effect of climate change treatments on ochratoxin A production by Aspergillus section Circumdati and Nigri species and strains at different water activity ( $\left.a_{w}\right)$ and temperatures using Kruskal-allis Test (non-normality data) and ANOVA (normality data; from Akbar et al., 2016). Numbers in parentheses refer to strain numbers). 
Temperature $30^{\circ} \mathrm{C}$

Factors

\begin{tabular}{|c|c|c|c|c|c|}
\hline Strains & $\mathrm{CO}_{2}$ & \multicolumn{3}{|c|}{$a_{w}$} & $\mathrm{a}_{w} \times \mathrm{CO}_{2}$ \\
\hline A. westerdijkiae (B 2) & $\mathbf{S}^{\mathbf{b}}$ & \multicolumn{3}{|c|}{$S^{\mathbf{b}}$} & $\mathrm{S}^{\mathrm{b}}$ \\
\hline A. westerdijkiae (CBS 121986) & $\mathbf{S}^{* b}$ & \multicolumn{3}{|c|}{$N S^{b}$} & $N S^{b}$ \\
\hline A. niger (A 1911) & $\mathbf{S}^{* \mathbf{b}}$ & \multicolumn{3}{|c|}{$\mathbf{S}^{\mathbf{b}}$} & $\mathrm{S}^{\mathrm{b}}$ \\
\hline A. carbonarius (ITAL 204) & $N S^{b}$ & \multicolumn{3}{|c|}{$S^{b}$} & $\mathrm{~S}^{\mathrm{b}}$ \\
\hline \multirow[t]{2}{*}{ A. ochraceus (ITAL 14) } & $\mathrm{NS}^{\mathrm{a}}$ & \multicolumn{3}{|c|}{$\mathbf{S}^{\mathbf{a}}$} & N/A \\
\hline & \multicolumn{4}{|c|}{ Temperature $35^{\circ} \mathrm{C}$} & \\
\hline A. westerdijkiae (B 2) & $\mathbf{S}^{\mathbf{a}}$ & $S^{a}$ & & N/A & \\
\hline A. westerdijkiae (CBS 121986) & $\mathbf{S}^{\mathbf{a}}$ & $N S^{a}$ & & N/A & \\
\hline A. niger (A 1911) & $\mathrm{NS}^{\mathrm{b}}$ & $\mathbf{S}^{\mathbf{b}}$ & & $\mathrm{NS}^{\mathrm{b}}$ & \\
\hline A. carbonarius (ITAL 204) & $\mathrm{NS}^{\mathrm{a}}$ & $\mathbf{S}^{\mathbf{a}}$ & & N/A & \\
\hline A. ochraceus (ITAL 14) & $\mathrm{NS}^{\mathrm{a}}$ & $\mathbf{S}^{\mathbf{a}}$ & & N/A & \\
\hline
\end{tabular}

Temperature $35^{\circ} \mathrm{C}$

\begin{tabular}{|c|c|c|c|}
\hline & $\mathrm{CO}_{2}$ (1000ppm) & $a_{w}$ & Temp $30+35^{\circ} \mathrm{C}$ \\
\hline A. westerdijkiae (B 2) & $\mathrm{NS}^{\mathrm{a}}$ & $\mathrm{NS}^{\mathrm{a}}$ & $\mathrm{S}^{\mathrm{a}}$ \\
\hline A. westerdijkiae (CBS 121986) & $\mathbf{S}^{\mathbf{a}}$ & $\mathrm{NS}^{\mathrm{a}}$ & $\mathrm{S}^{\mathrm{a}}$ \\
\hline A. niger (A 1911) & $N S^{a}$ & $\mathrm{NS}^{\mathrm{a}}$ & $\mathrm{S}^{\mathrm{a}}$ \\
\hline A. carbonarius (ITAL 204) & $N S^{a}$ & $S^{a}$ & $\mathrm{NS}^{\mathrm{a}}$ \\
\hline A. ochraceus (ITAL 14) & $\mathrm{NS}^{\mathrm{a}}$ & $\mathrm{NS}^{\mathrm{a}}$ & $\mathrm{S}^{\mathrm{a}}$ \\
\hline
\end{tabular}

$S$ significant $(P<0.05)$

NS not significant $(P>0.05)$

${ }^{a}$ Kruskal-Wallis test

${ }^{b}$ ANOVA

N/A Not Applicable 


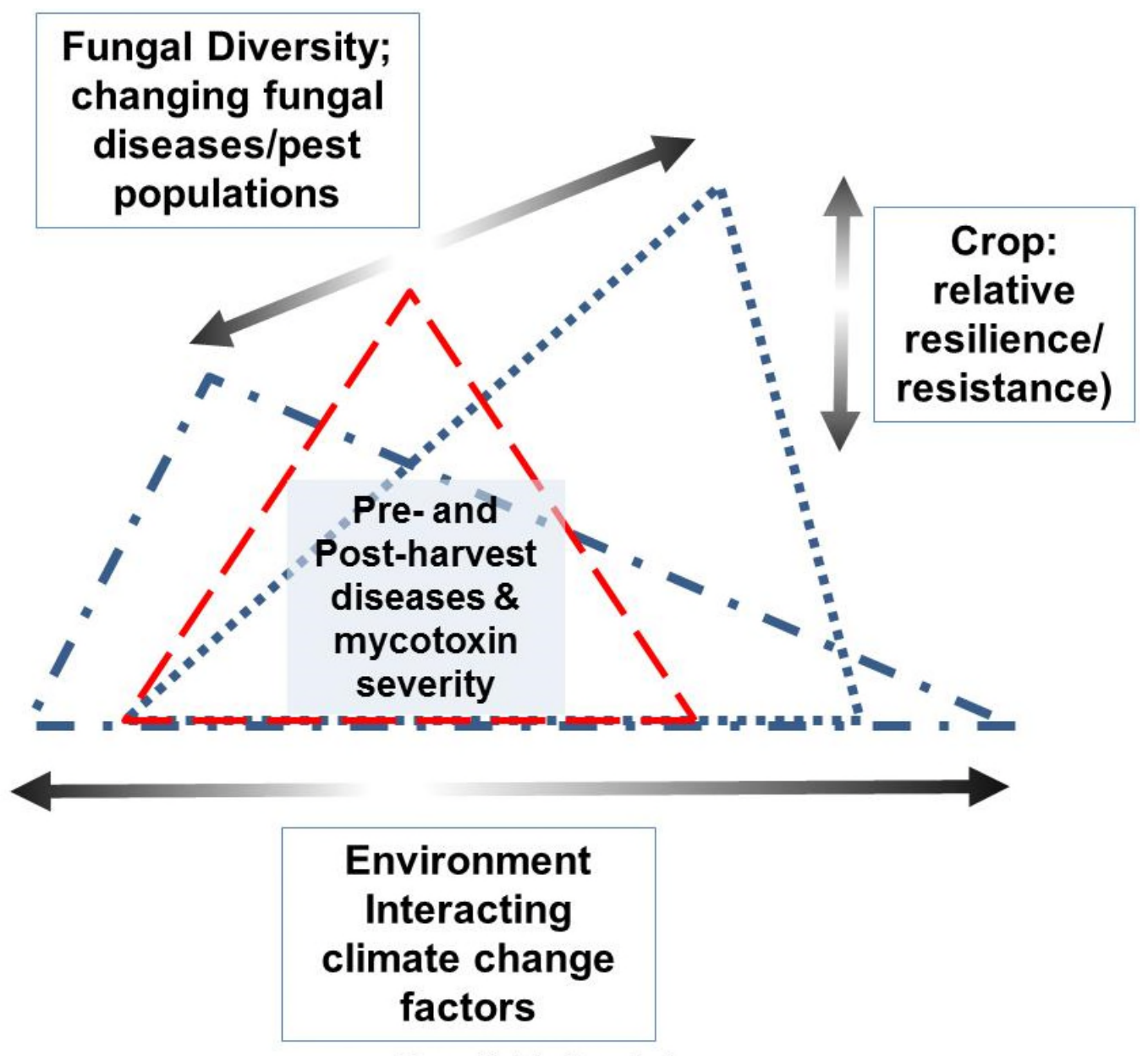

Figure 1. Medina et al. 


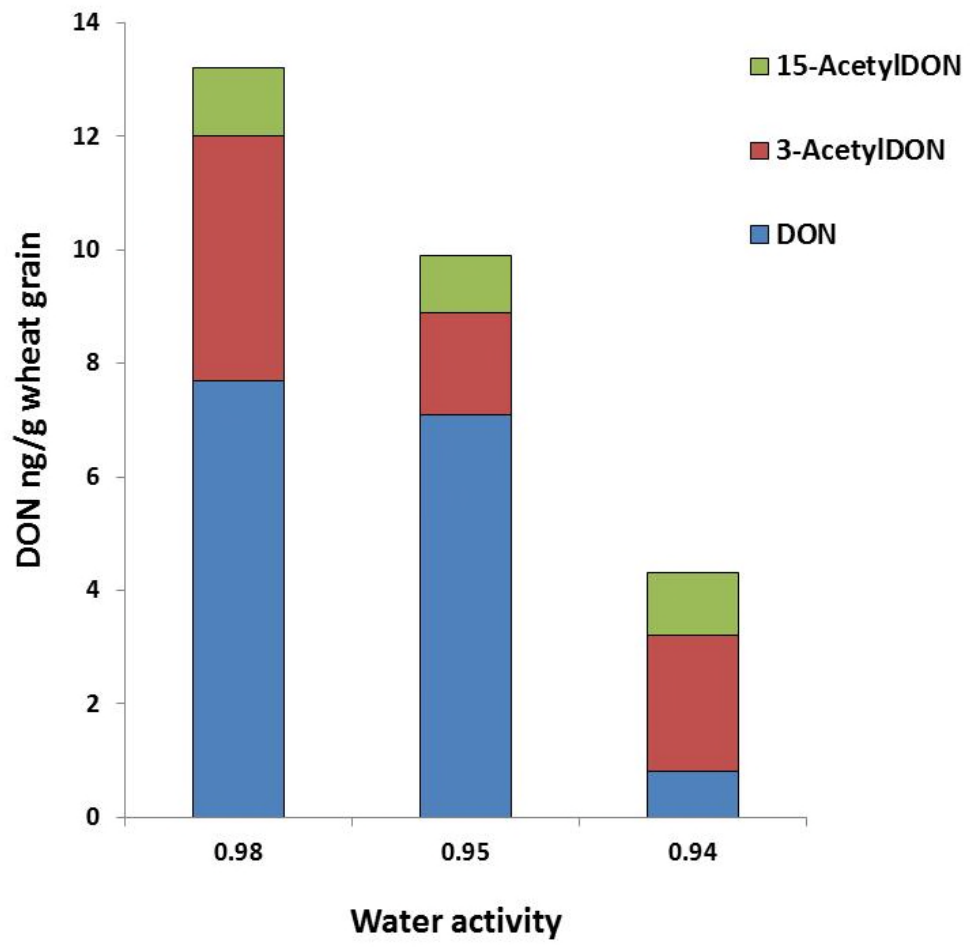

Figure 2. Medina et al. 
(a) A. westerdijkiae (CBS 121986) at $30^{\circ} \mathrm{C}$

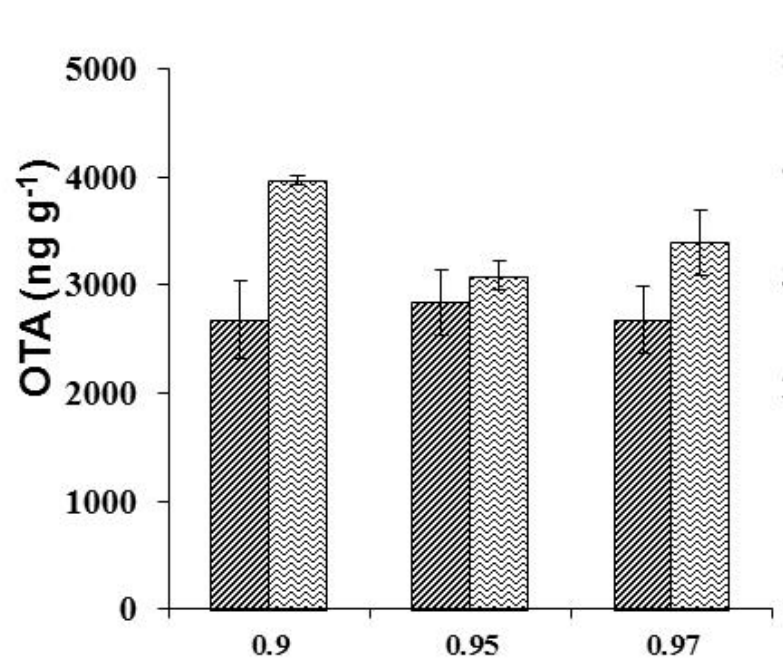

(b) A. westerdijkiae (CBS 121986) at $3^{\circ} \mathrm{C}$

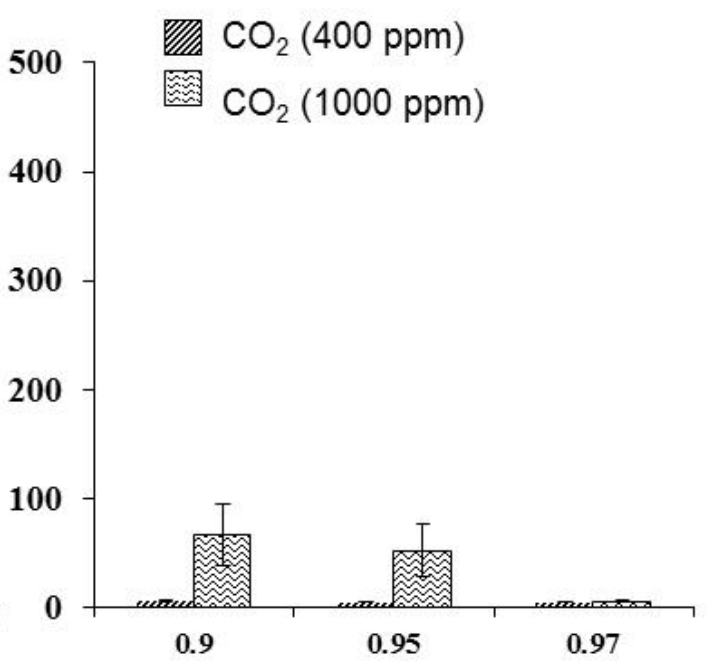

\section{Water activity}

(c) A. carbonarius (ITAL 204) at $30^{\circ} \mathrm{C}$

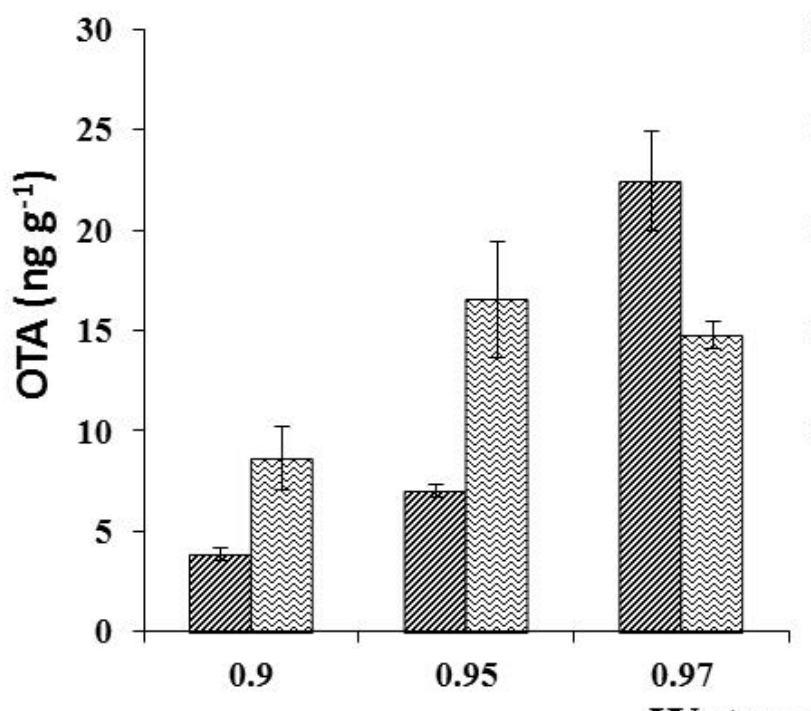

(d) A. carbonarius (ITAL 204) at $35^{\circ} \mathrm{C}$

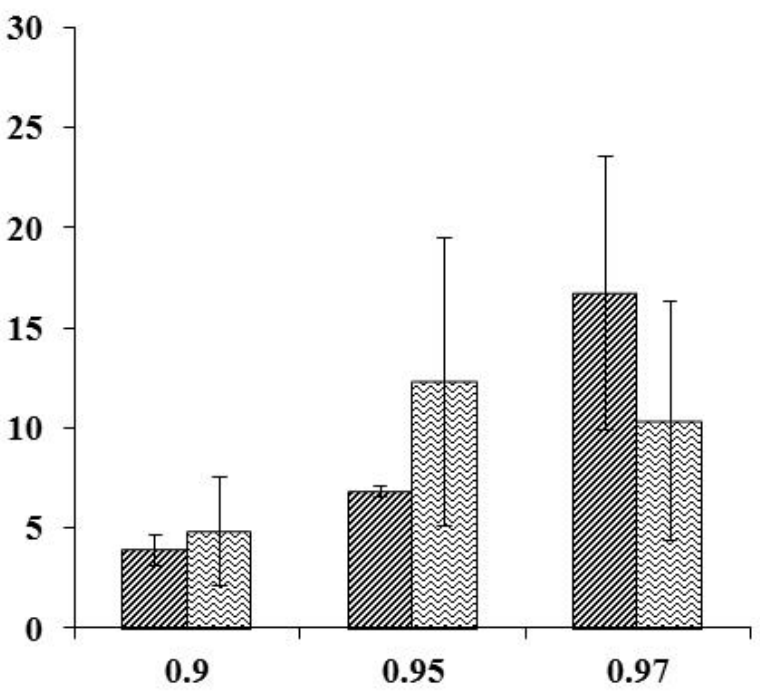

Water activity

Figure 3. Medina et al. 


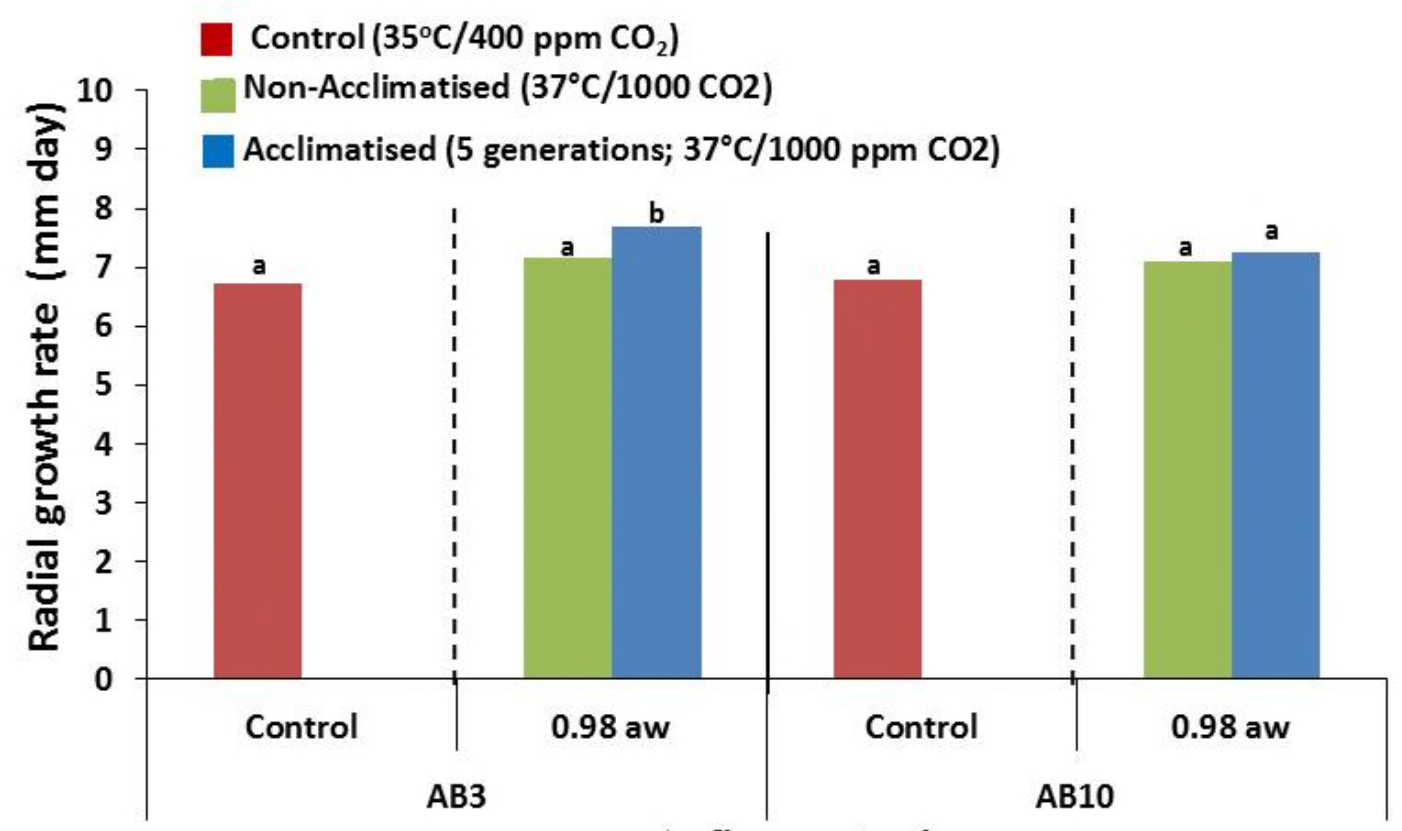

A. flavus strain

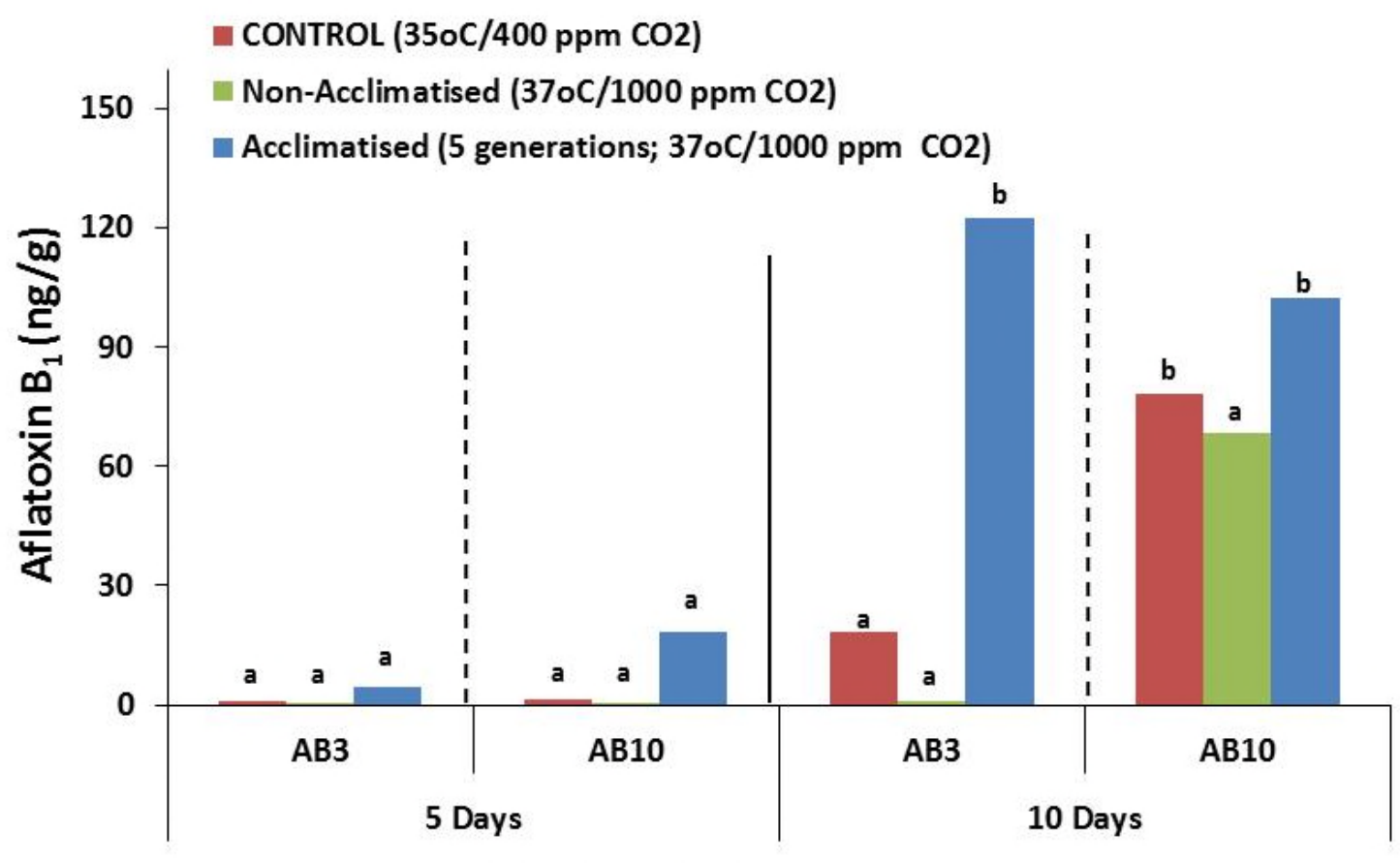

A. flavus strain/storage period

Figure 4. Medina et al. 